\title{
PEMBUATAN FILE SYSTEM GLUSTERFS DISTRIBUTED- REPLICATED VOLUME DI SEKOLAH VOKASI IPB UNIVERSITY
}

\author{
Aep Setiawan', Rifa Ade Rahmah ${ }^{2}$ \\ 1,2 Teknik Komputer, Sekolah Vokasi IPB University \\ email: aepsetiawan@apps.ipb.ac.id
}

\begin{abstract}
Abstrak: Sekolah Vokasi IPB University (SV-IPB) menggunakan sistem client-server sebagai arsitektur teknologi informasi. Server tersebut menyediakan beberapa layanan yang digunakan untuk membantu proses belajar mengajar di Sekolah Vokasi IPB. Aplikasi yang digunakan untuk memberikan pelayanan yaitu Modular Object-Oriented Dynamic Learning Environment (MOODLE) yang digunakan untuk pembelajaran secara e-learning. SV-IPB menyediakan dua Virtual Machine yang digunakan sebagai web server dan database server. Penggunaan single web server untuk menampung ribuan request tentu kurang stabil karena tidak terdapat web server cadangan apabila server tersebut down sehingga layanan akan terhenti. Keadaan tersebut memperlihatkan bahwa penggunaan single web server tidak memiliki ketersediaan yang tinggi (high available). Mengatasi masalah tersebut dapat digunakan teknologi cluster yang digunakan untuk mengelompokkan beberapa web server di SV-IPB. Teknologi clustering web server yang digunakan yaitu menggunakan Gluster File System (GlusterFS) dengan tipe volume yang digunakan yaitu Distributed-replicated volume. Berdasarkan pengujian yang telah dilakukan, proyek ini dapat menangani permasalahan yang telah dipaparkan sebelumnya yaitu apabila salah satu web server down, masih terdapat web server lain yang dapat sehingga tidak proses request client tidak terhenti. Selain itu, teknologi clustering yang digunakan dibutuhkan untuk penggunaan load balancing web server sehingga dapat mengurangi beban setiap server karena proses request akan dikirimkan secara bergantian antar-web server.
\end{abstract}

Kata Kunci: Brick, Distributed-replicated volume, GlusterFS, Node

Abstract: College of Vocational IPB University (SV-IPB) uses a client-server system as an information technology architecture. The server provides several services used to assist the teaching and learning process at the IPB Vocational School. The application used to provide services is the Modular Object-Oriented Dynamic Learning Environment (MOODLE), used for e-learning. SV-IPB provides two Virtual Machines, which are used as a web server and a database server. Using a single webserver to replace the request is less stable because there is no webserver to back it up so that the service will stop. This situation states that using a single web server does not have high information (high availability). To overcome this problem, the cluster technology can be used to group several web servers in SV-IPB. The web server clustering technology used is the Gluster File System (GlusterFS) with the volume type used, namely Distributed-replicated volume. Based on the tests carried out, this project can solve the problem described earlier that "one web server is down, there is still another web server that can make so that the client request process does not stop. In addition, the clustering technology used is required for the use of load balancing web servers to reduce the load on each server because the request process will be sent alternately between web servers.

Keywords: Brick, Distributed-replicated volume, GlusterFS, Node

\section{PENDAHULUAN}

Setiap tahunnya, terdapat ribuan jumlah mahasiswa baru di Sekolah Vokasi IPB. Banyaknya jumlah mahasiswa baru tersebut menyebabkan masalah baru ketika dilakukan pendataan akademik. Selain itu, terdapat pula permasalahan lainnya yaitu ketika penilaian tugas mahasiswa dan penyimpanan tugas tersebut. Salah satu sistem yang dapat digunakan untuk mengatasi masalah tersebut yaitu menggunakan sistem client-server. Sistem clientserver adalah pembagian kerja antara server dan client yang mengakses server dalam suatu jaringan [1].

Saat ini, Sekolah Vokasi IPB telah menggunakan sistem client-server. Server tersebut menyediakan beberapa layanan yang digunakan untuk membantu proses belajar mengajar di Sekolah Vokasi IPB. Salah satu sistem yang digunakan yaitu Learning Manangement System (LMS). LMS merupakan sebuah sistem yang terintegrasi dan komprehensif serta dapat digunakan sebagai platform e-learning [2]. Terdapat beberapa teknologi LMS yang bersifat open source, salah satunya yaitu MOODLE. Modular Object-Oriented Dynamic Learning Environment (MOODLE) merupakan sebuah program aplikasi yang dapat merubah media pembelajaran ke dalam bentuk web. Manfaat dari penggunaan LMS menggunakan MOODLE secara online sangat penting, diantaranya adalah mengatasi keterbatasan frekuensi tatap muka antara mahasiswa dengan dosen [3]. Selain sistem yang disiapkan untuk kebutuhan e-learning, keamanan jaringan computer yang disiapkan sudah memadai untuk mendukung server. Keamanan jaringan komputer atau Computer Network Security sangat berhubungan dengan keamanan data, oleh karena itu keamanan jaringan sangat penting untuk melindungi 
data dari berbagai serangan pihak - pihak yang tidak bertanggung jawab [4]

Web server pada jaringan di Sekolah Vokasi IPB University yaitu single web server yang artinya hanya terdapat satu web server di Sekolah Vokasi IPB University. Penggunaan satu web server menyebabkan server tidak memiliki keandalan yang tinggi (high available) karena apabila tersebut down maka tidak terdapat backup data sehingga LMS tidak dapat di akses. Data merupakan bagian yang sangat penting yang terdapat pada server, data-data tersebut kemudian akan digunakan untuk pengambilan keputusan di dalam proses pembelajaran e-learning. Pengelolaan data yang buruk dapat mengakibatkan tidak tersedianya data penting yang digunakan untuk menghasilkan informasi yang diperlukan dalam pengambilan keputusan [5]. Mengingat pentingnya suatu data, maka perlu adanya backup. Backup merupakan arsip yang dapat diambil sewaktu dibutuhkan. Selain itu adanya backup dapat menghindari hilangnya data pada web server.

Penggunaan single web server juga mengakibatkan beban kerja server menjadi berat. Beban server yang tinggi dapat mengakibatkan proses pada website lambat. Lambatnya proses load pada server juga menandakan bahwa server tidak andal dalam berproses. Menghindari kemungkinan tersebut dapat dilakukan beberapa perbaikan, salah satunya yaitu mengoperasikan beberapa server secara serentak. Pengoperasian beberapa server secara serentak dapat meminimalisir kerja server karena request dapat dialihkan ke beberapa server sekaligus, dan juga dapat mengurangi antrian request yang terdapat pada server. Selain itu penggunaan beberapa server secara serentak dapat menjadi backup apabila server lainnya mati.

Dalam pengoperasian server secara serentak, terdapat beberapa hal yang harus diperhatikan salah satunya yaitu data yang dimiliki oleh semua server tersebut harus sama sehingga dapat dilakukan proses load balancing. Untuk pendistribusian data tersebut dapat digunakan beberapa cara salah satunya yaitu menggunakan cluster. Cluster adalah sekelompok mesin yang bertindak sebagai sebuah entitas tunggal untuk menyediakan sumber daya dan layanan ke jaringan [6].

Dalam penerapan cluster dapat digunakan aplikasi salah satunya yaitu GlusterFS. GlusterFS merupakan aplikasi open source yang bermanfaat untuk ruang penyimpanan untuk manajemen sistem berkas terdistribusi, aplikasi ini memiliki berbagai karakteristik seperti scalable, reliable, ekspansi disk yang fleksibel [7]. GlusterFS didesain untuk memenuhi kebutuhan ruang penyimpanan bagi pengguna dan dapat memberikan kinerja yang luar biasa untuk beban kerja yang beragam [8]. Penggunaan GlusterFS ini berfungsi untuk proses distribusi file sehingga file MOODLE yang terdapat di antara server tersebut dapat sinkron sehingga dapat menghindari terjadinya kesalahan dalam proses belajar mengajar.

Dalam terminologi Gluster, terdapat volume yang merupakan bagian dari server yang menampung sistem file ruang kernel aktual untuk penyimpanan data dan pengeksposan data kepada klien. Setiap volume dapat dibangun oleh beberapa subvolume, umumnya di-hosting oleh server yang berbeda. Subvolume dibangun oleh brick, sistem penyimpanan file yang telah ditetapkan untuk volume, diproses oleh setidaknya satu penerjemah [9].

\section{TINJAUAN PUSTAKA}

\section{Cluster}

Cluster adalah sekelompok mesin yang bertindak sebagai sebuah entitas tunggal untuk menyediakan sumber daya dan layanan ke jaringan [6]. Cluster adalah sekumpulan komputer (umumnya server jaringan) independen yang beroperasi serta bekerja secara erat dan terlihat oleh klien jaringan seolah-olah komputer-komputer tersebut adalah satu buah unit computer [10].

Berdasarkan kedua sumber sebelumnya, cluster merupakan gabungan dari beberapa server dan dipandang sebagai satu sistem tunggal yang menangani layanan yang terdapat di dalam jaringan. Terlihat seperti satu sistem yang tunggal akan dirasakan oleh client yang melakukan request ke server. Apabila salah satu server mengalami down, client yang melakukan request tidak akan menyadari kondisi tersebut karena request langsung dikerjakan oleh server lainnya yang telah di clustering.

Salah satu karakteristik utama komputer cluster adalah konsep single entity di mana kumpulan banyak komputer yang menjadi komputer cluster dipandang sebagai satu kesatuan sistem tunggal [11]. Teknologi cluster ini memiliki beberapa kelebihan, salah satunya menghasilkan suatu sistem dengan tingkat reliability dan availability tinggi atau yang biasa disebut high availability server [12].

\section{Web server \\ Web server merupakan komputer yang digunakan untuk menyimpan dokumen- dokumen web, komputer ini melayani permintaan dokumen web dari kliennya [12]. web server merupakan software yang memberikan layanan data, berfungsi menerima permintaan HTTP dan HTTPS dari client yang dikenal dengan browser web dan mengirimkan kembali hasilnya dalam bentuk halaman- halaman web yang umumnya berbentuk dokumen HTML [13].}




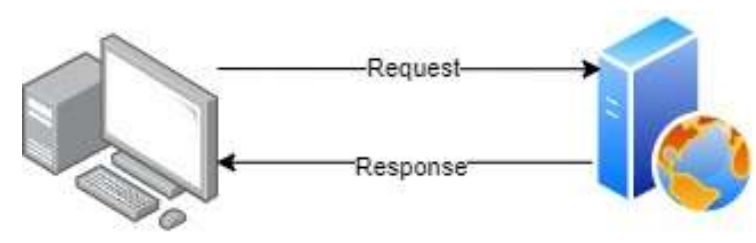

Gambar 1 Ilustrasi cara kerja web server

Gambar 1 menampilkan ilustrasi dari web server. Web server berfungsi untuk memberikan layanan kepada client. Apabila client memberikan request, selanjutnya web server mengembalikan permintaan client tersebut jika data yang yang di-request tersedia pada server. Sedangkan apabila data yang diinginkan tidak tersedia maka server mengembalikan halaman yang menyatakan bahwa halaman yang diminta tidak tersedia. Halaman yang di-request biasanya berekstensi HTML, PHP, CSS atau lainnya [11].

\section{File System}

File System atau Sistem Fail merupakan gabungan dari dua kata yaitu sistem dan fail. Menurut Kamus Besar Bahasa Indonesia, kata sistem berarti 1) perangkat unsur yang secara teratur saling berkaitan sehingga membentuk suatu totalitas, 2) susunan yang teratur dari pandangan, teori, asas, dan sebagainya, 3) metode. Sedangkan fail dapat diartikan sebagai dokumen atau berkas. Sistem file merupakan suatu metode untuk memberi nama pada file dan meletakannya pada media penyimpanan. Jadi file system dapat diartikan sebagai metode yang digunakan untuk mengatur berbagai hal yang berhubungan dengan dokumen atau berkas sehingga susunannya menjadi teratur [14].

\section{GlusterFS}

GlusterFS merupakan aplikasi yang bersifat open source yang bermanfaat untuk proses berbagi file antar server. GlusterFS adalah solusi open-source untuk kebutuhan sistem berkas terdistribusi dengan biaya rendah dan terukur untuk memenuhi kebutuhan penyimpanan dari berbagai lingkungan [12].

GlusterFS didesain untuk memenuhi kebutuhan ruang penyimpanan bagi pengguna dan dapat memberikan kinerja yang luar biasa untuk beban kerja yang beragam [8]. Selain digunakan untuk memenuhi ruang penyimpanan, GlusterFS juga dapat digunakan untuk mem-backup data server apabila salah satu server down sehingga data tetap aman dan dapat sinkron kembali. GlusterFS juga dapat menangani ribuan client sehingga pemrosesan dapat dilakukan pada banyak gluster client sehingga dapat dilakukan pembagian request pada setiap server.
Dalam terminologi Gluster, volume merupakan bagian dari server yang menampung sistem file ruang kernel aktual untuk penyimpanan data dan pengeksposan data kepada klien. Setiap volume dapat dibangun oleh beberapa subvolume, umumnya di-hosting oleh server yang berbeda. Subvolume dibangun oleh brick, sistem penyimpanan file yang telah ditetapkan untuk volume, diproses oleh setidaknya satu penerjemah [9].

Pada GlusterFS terdapat 3 jenis volume yaitu distributed, replication, dan striped. Distributed volume merupakan jenis volume yang menyebarkan data ke setiap brick yang tersedia. Data didistribusikan ke satu brick, sedangkan data lainnya didistribusikan ke brick lainnya. Topologi dari Distributed volume yaitu dapat dilihat pada Gambar 2.

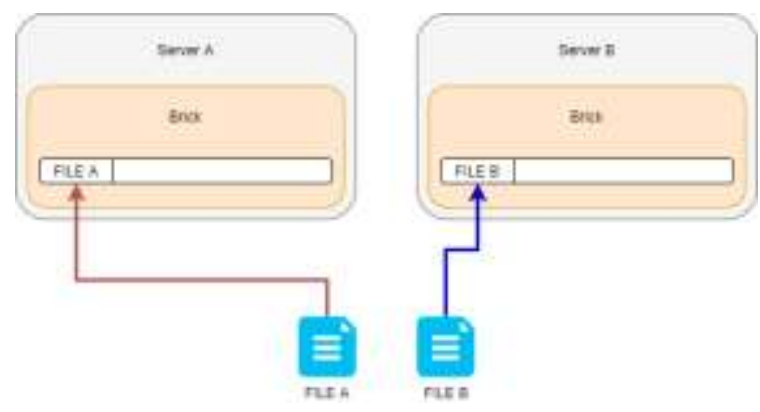

Gambar 2 GlusterFS distributed volume

Sementara itu penyebaran data pada replication volume dilakukan ke semua brick secara bersamaan sehingga data yang terdapat pada setiap brick sama. Topologi dari replication volume yaitu terlihat pada Gambar 3.

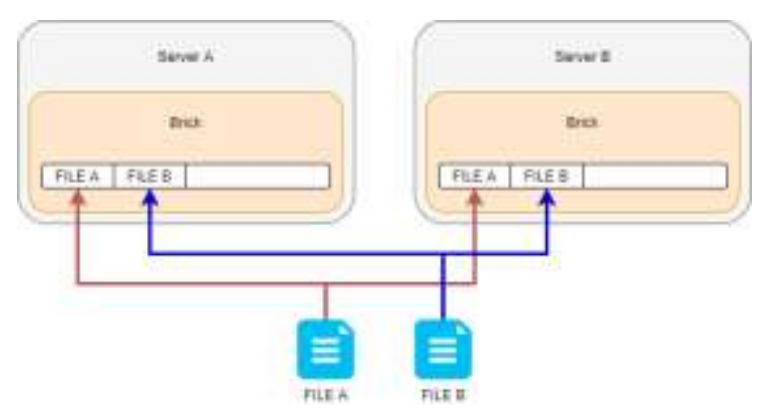

Gambar 3 GlusterFS replicated volume

Pada stripped volume, setiap data dipecah menjadi beberapa bagian dan didistribusikan ke setiap brick sehingga setiap brick menyimpan bagian dari setiap data. Topologi dari stripped volume yaitu terlihat pada Gambar 4 . 


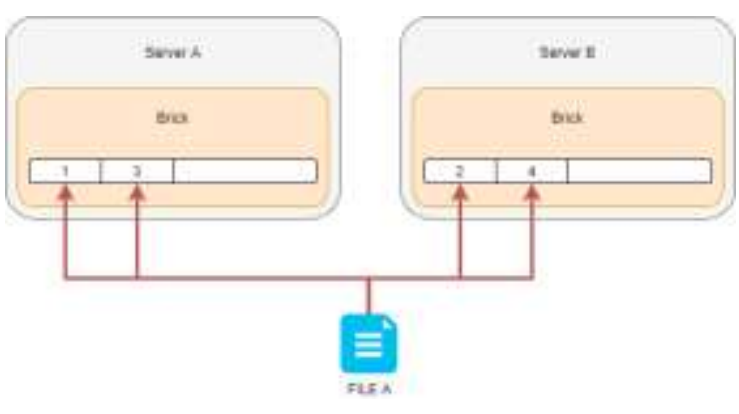

Gambar 4 GlusterFS stripped volume

\section{METODE}

Alat dan bahan yang digunakan dalam proses Pembuatan File System GlusterFS Distributedreplicated volume di Sekolah Vokasi IPB University terdapat pada Tabel 1.

Tabel 1 Alat dan Bahan

\begin{tabular}{|c|c|c|}
\hline No & Alat dan Bahan & Spesifikasi \\
\hline 1 & $\begin{array}{l}\text { Laptop Dell Inspiron } \\
\text { N4050 }\end{array}$ & $\begin{array}{l}\text { Processor Core } \\
\text { i5-2410M, RAM } \\
6 \mathrm{~GB}\end{array}$ \\
\hline 2 & Server PX1 & $\begin{array}{lr}\text { Processor } & \text { Intel } \\
\text { Xeon, } & \text { RAM } \\
32 \mathrm{~GB} & \end{array}$ \\
\hline 3 & Server PX2 & $\begin{array}{l}\text { Proccessor Core } \\
\text { i7-3770K, RAM } \\
12 \mathrm{~GB}\end{array}$ \\
\hline 4 & File ISO Ubuntu Server & Versi 18.04 \\
\hline 5 & WSL Ubuntu 18.04 LTS & Versi 18.04 \\
\hline
\end{tabular}

Prosedur kerja dari Pembuatan File System GlusterFS Distributed-replicated volume di Sekolah Vokasi IPB University yaitu dapat dilihat pada Gambar 55.

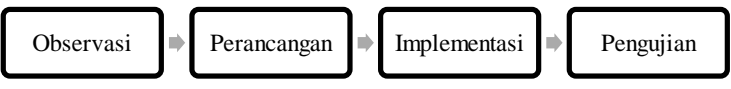

Gambar 5 Prosedur Kerja

\section{Observasi}

Tahap observasi bertujuan untuk mengamati dan mencari informasi yang terdapat pada Sekolah Vokasi IPB University. Berdasarkan informasi yang didapatkan tersebut, dilakukan proses pencarian masalah dengan melihat sumber daya yang tersedia di SV-IPB. Masalah yang didapatkan dari proses observasi digunakan untuk mencari solusi dari permasalahan tersebut. Observasi dilakukan dengan mencari kelemahan yang terjadi di Sekolah Vokasi IPB, terutama pada server $e$ learning yang berjalan.

\section{Perancangan}

Tahap perancangan berfungsi untuk merumuskan solusi dari masalah yang didapatkan pada tahap sebelumnya. Proses perancangan dilakukan dengan membuat rancangan skema GlusterFS yang digunakan dan melakukan proses perancangan topologi jaringan yang terdapat di Sekolah Vokasi IPB University. Pada proses perancangan juga dilakukan pembuatan skenario uji untuk GlusterFS yang telah diterapkan.

\section{Implementasi}

Tahap implementasi bertujuan untuk menindaklanjuti rancangan yang telah dibuat pada tahap perancangan. Implementasi tersebut dilakukan dengan melakukan proses konfigurasi pada server sehingga didapatkan hasil yang sesuai dengan rancangan yang telah dibentuk.

\section{Pengujian}

Tahap pengujian merupakan tahap yang dilakukan untuk menguji fungsi dari GlusterFS yang telah dikonfigurasi pada tahap implementasi. Proses pengujian dilakukan dengan menggunakan beberapa kemungkinan seperti proses pembuatan file dan direktori serta penghapusan file dan direktori yang terdapat pada GlusterFS.

\section{HASIL DAN PEMBAHASAN}

Pada bagian pembahasan akan dijabarkan proses dan hasil dari tahap pengujian proses cluster dengan menggunakan file system GlusterFS dengan tipe volume distributed-replicated. Pengujian yang dilakukan yaitu pemeriksaan penyimpanan data pada setiap server dan membandingkan kinerja single web server dan multi web server.

\section{Pengujian GlusterFS dengan tipe volume distributed-replicated}

Pengimplementasian GlusterFS pada server di SV-IPB menggunakan 2 node yang berfungsi sebagai gluster server dan 2 node yang berfungsi sebagai gluster client. Tipe volume yang digunakan yaitu distributedreplicate seperti yang terlihat pada Gambar 66.

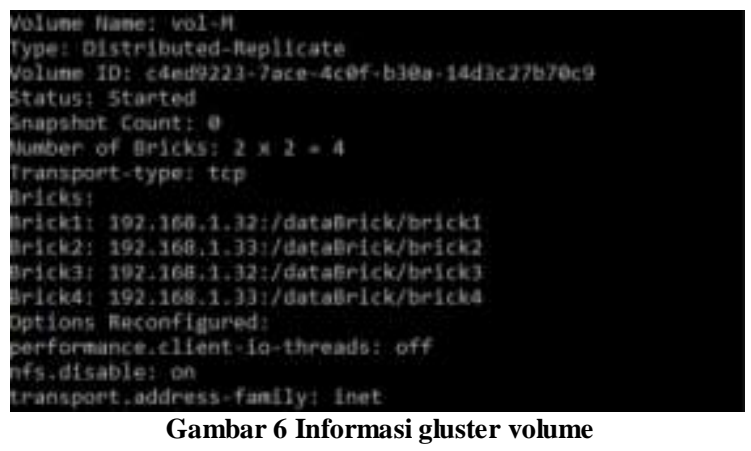

Pada Gambar 6 terdapat informasi mengenai Number of Brick yaitu $2 \times 2=4$. Informasi tersebut memiliki makna yaitu 
terdapat 2 brick yang akan digunakan sebagai distributed dan terdapat 2 brick yang digunakan sebagai replicate. Brick yang di-replicate yaitu brick 1 dan brick 2 dan juga brick 3 dan brick 4. Selanjutnya untuk penyimpanan file akan disimpan secara acak pada setiap brick yang telah di-replicate.

Pengujian GlusterFS ini dilakukan dengan membuat file dan direktori di salah satu gluster client kemudian dilakukan pengecekan pada gluster server. Proses penyimpanan pada GlusterFS dengan tipe volume distributedreplicate yaitu terlihat pada Gambar 77 .

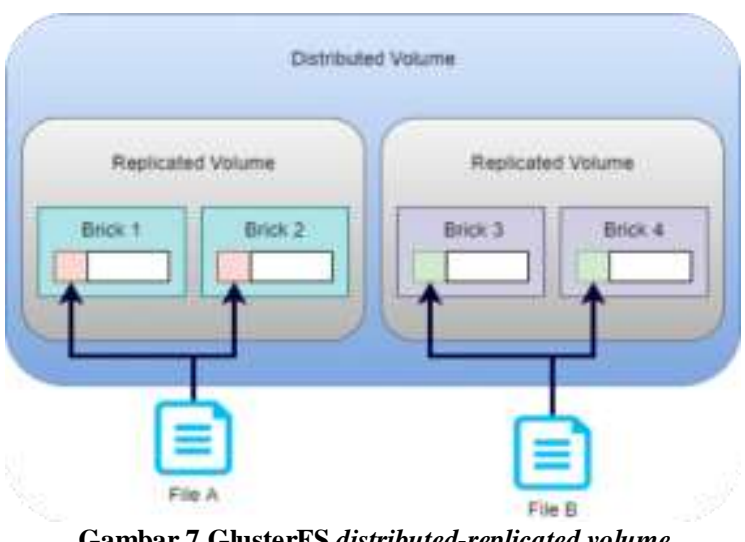

Gambar 7 GlusterFS distributed-replicated volume

Pengujian membuat direktori pada gluster client dilakukan pada salah satu node gluster client. Proses pembuatan direktori tersebut terdapat pada Gambar 88.

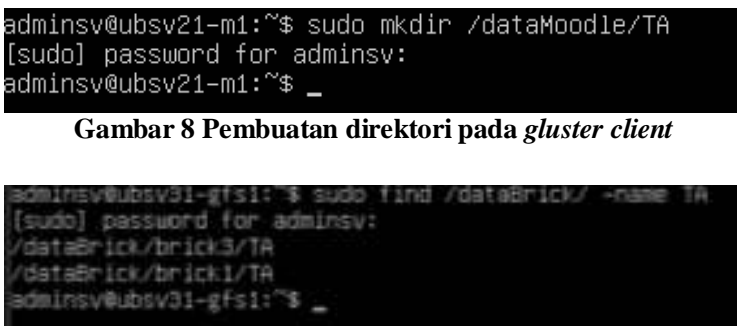

Gambar 9 Pencarian pada gluster server 1

Gambar 9 menampilkan penyimpanan direktori TA di node 1. Direktori tersebut tersimpan pada setiap brick yang ada di node 1 yaitu brick 3 dan brick 1. Semua brick tersimpan pada direktori yang sama yaitu pada direktori /dataBrick.

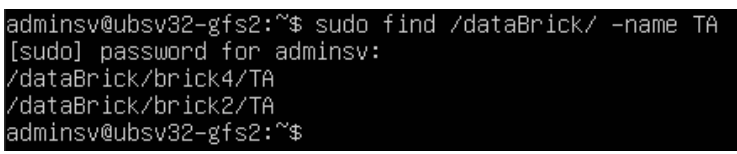

Gambar 10 Pencarian pada gluster server 2

Gambar 10 menampilkan penyimpanan direktori TA di node 2 yaitu pada brick 4 dan brick 4. Berdasarkan penyimpanan direktori tersebut, didapatkan kesimpulan bahwa untuk setiap penambahan direktori pada gluster client maka setiap brick juga menambah direktori yang sama.

Pengujian lainnya yaitu menambahkan file dengan ekstensi TXT. Gambar 11 merupakan proses pembuatan file TEK.txt pada node $\mathrm{m} 2$ yang merupakan gluster client dalam GlusterFS ini.

\section{adminsveubsve2-me: ${ }_{s}$}

\section{Gambar 11 Pembuatan file TEK.txt}

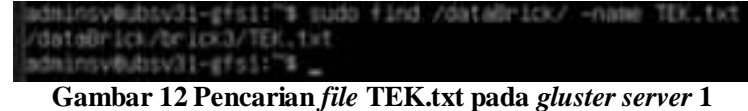

Gambar 12 menampilkan penyimpanan file TEK.txt pada node gluster server 1. File tersebut tersimpan hanya pada brick 3, sedangkan brick 1 tidak menyimpan file TEK.txt. penyimpanan file secara acak pada brick merupakan bagian dari tipe volume distributed. Distributed volume merupakan jenis volume yang menyebarkan data ke setiap brick yang tersedia. Data didistribusikan ke satu brick, sedangkan data lainnya di distribusikan ke brick lainnya.

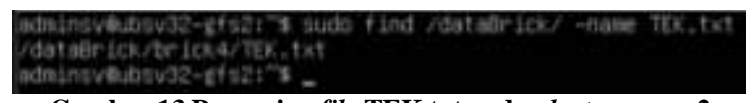

Gambar 13 Pencarian file TEK.txt pada gluster server 2

Gambar 13 menampilkan penyimpanan file TEK.txt pada node gluster server 2. File tersebut tersimpan hanya pada brick 4. Penyimpanan hanya pada salah satu brick menjelaskan penerapan tipe volume distributed, sedangkan penyimpanan file yang sama pada beberapa brick menjelaskan penerapan tipe volume replicate. Brick yang direplicate pada proyek ini yaitu brick 1 dengan brick 2 dan brick 3 dengan brick 4 . Berdasarkan penyimpanan file TEK.txt pada gluster server 1 dan gluster server 2, file TEK.txt telah di-replicate yaitu antara brick 3 dan brick 4. Sedangkan brick 1 dan brick 2 tidak menyimpan file TEK.txt menerapkan tipe volume distributed.

2. Perbandingan single web server dengan multi web server

Pengujian lainnya yaitu ditinjau dari kecepatan server ketika hanya terdapat satu web server (single web server) dan multi web server. Pengujian dilakukan untuk menguji pengaruh dari pembaruan infrastruktur terhadap kecepatan server. Tool yang digunakan dalam pengujian ini yaitu httperf untuk menguji performa dari web server. 


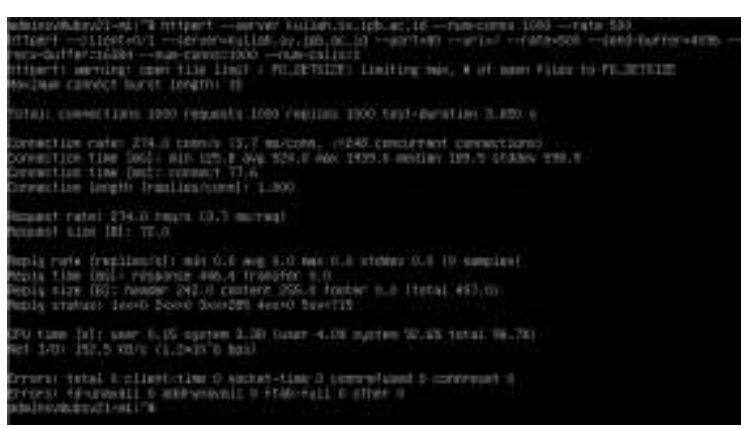

Gambar 94 HTTPERF single web server dengan jumlah koneksi 1000

Gambar 94 menampilkan pengujian httperf dengan menggunakan 1000 koneksi dengan banyak request 500 per detik. Hasil dari pengujian terlihat pada total yang menampilkan jumlah koneksi yang berhasil dan durasi dari pengujian. Koneksi yang berhasil dari pengujian tersebut yaitu 1000 dari 1000 koneksi yang diuji yang artinya semua koneksi berhasil diproses dengan waktu 3.650 s. Sedangkan untuk total error yaitu 0 karena semua koneksi berhasil di proses.

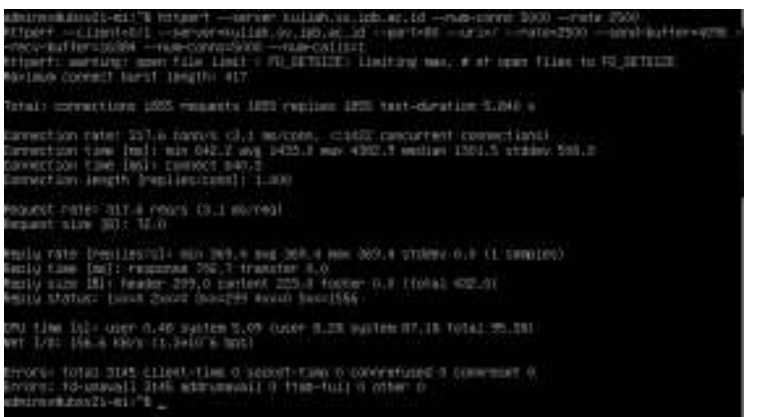

Gambar 105 HTTPERF single web server dengan jumlah koneksi 5000

Gambar 105 menampilkan pengujian dengan menggunakan koneksi 5000 dengan request 2500 per detik. Pengujian tersebut menampilkan total durasi yaitu 5,840 s dengan koneksi yang berhasil yaitu 1855 dari 5000 koneksi yang diujikan. Pengujian tersebut juga mengalami error sebanyak 3145.

Pengujian untuk infrastruktur multi web server dilakukan dua tahapan dengan jumlah koneksi dan request sama seperti pengujian pada single web server. Pengujian dilakukan dengan menggunakan IP address dari web server.

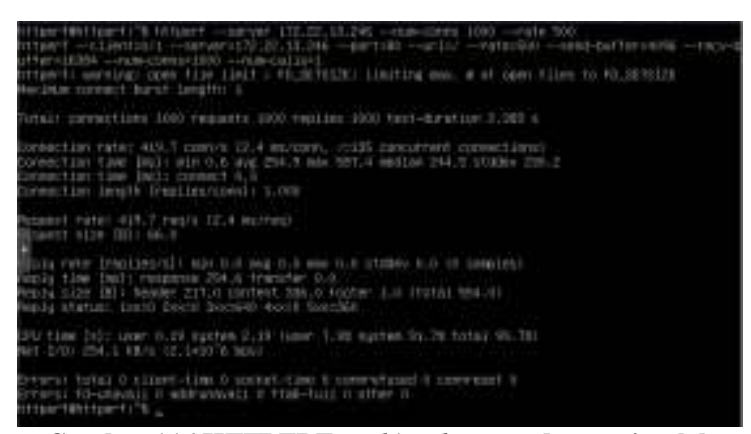

Gambar 116 HTTPERF multi web server dengan jumlah koneksi 1000

Gambar 116 merupakan pengujian web server setelah dilakukan perubahan infrastruktur. Pengujian ini dilakukan dengan menggunakan 1000 koneksi dengan request sebanyak 500 per detik. Hasil dari pengujian ini yaitu koneksi yang berhasil dilakukan yaitu 1000 dari 1000 koneksi yang diuji. Waktu yang dibutuhkan untuk pengujian tersebut yaitu 2.383 s sedangkan untuk koneksi yang error yaitu 0 .

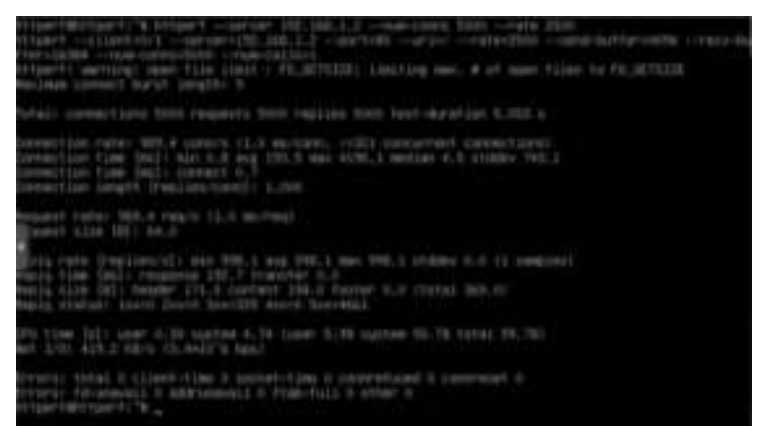

Gambar 127 HTTPERF multi web server dengan jumlah koneksi 5000

Gambar 127 merupakan pengujian pada multi web server dengan menggunakan 5000 koneksi dengan 2500 request. Hasil dari pengujian tersebut yaitu total koneksi yang berhasil 5000 dari 5000 koneksi yang diuji. Waktu yang dibutuhkan untuk pengujian tersebut yaitu $5.053 \mathrm{~s}$ dengan total error yaitu 0 koneksi.

Berdasarkan beberapa perbandingan yang dilakukan antara single web server dengan multi web server dapat dikelompokkan seperti yang ditampilkan pada Tabel 2.

Tabel 2 Perbandingan single web server dan multi web server

\begin{tabular}{|c|c|c|c|c|c|c|c|}
\hline \multirow[b]{2}{*}{ No } & \multirow[b]{2}{*}{$\begin{array}{c}\text { Penguj } \\
\text { ian }\end{array}$} & \multicolumn{3}{|c|}{ Single web server } & \multicolumn{3}{|c|}{ Multi web server } \\
\hline & & $\begin{array}{r}\text { Total } \\
\text { Konek } \\
\text { si } \\
\end{array}$ & $\begin{array}{l}\text { Total } \\
\text { Error }\end{array}$ & $\begin{array}{r}\text { Test- } \\
\text { Durat } \\
\text { ion } \\
\end{array}$ & $\begin{array}{r}\text { Total } \\
\text { Koneks } \\
\mathrm{i} \\
\end{array}$ & $\begin{array}{l}\text { Total } \\
\text { Error }\end{array}$ & $\begin{array}{r}\text { Test- } \\
\text { Dura } \\
\text { tion }\end{array}$ \\
\hline & Koneksi & & & & & & \\
\hline 1 & 1000 & 1000 & 0 & $650 \mathrm{~s}$ & 1000 & 0 & $383 \mathrm{~s}$ \\
\hline & $\begin{array}{r}\text { Request } 500 \\
\text { Koneksi }\end{array}$ & & & & & & \\
\hline 2 & $\begin{array}{r}5000 \\
\text { Request } \\
2500\end{array}$ & 1855 & 3145 & $840 \mathrm{~s}$ & 5000 & 0 & $053 \mathrm{~s}$ \\
\hline
\end{tabular}


Tabel 2 menampilkan perbandingan penggunaan single web server dengan multi web server di Sekolah Vokasi IPB University. Penggunaan server dengan 1000 koneksi hingga 2000 koneksi apabila menggunakan single web server berjalan dengan baik, begitu pula ketika server bekerja dengan multi web server. Perbedaan dari single web server dan multi web server ketika diuji dengan 1000 koneksi dengan 500 request yaitu pada sisi waktu pengujian. Pengujian dengan menggunakan multi web server dapat berjalan lebih cepat dibandingkan dengan menggunakan single web server.

Perngujian kedua yaitu menggunakan 5000 koneksi dengan 2500 request. Pada pengujian ini terdapat koneksi yang error sebanyak 3145 koneksi pada single web server. Sedangkan untuk pengujian multi web server tidak terdapat error dengan waktu yang lebih cepat dibanding single web server dengan perbedaan beberapa ms.

Berdasarkan pengujian tersebut, multi web server berjalan lebih baik dibandingkan dengan single web server. Single web server berjalan dengan baik ketika koneksi berada dalam kisaran 1000-2000 koneksi, sedangkan apabila server telah menerima koneksi sangat lebih dari kisaran tersebut maka akan terdapat banyak paket lose. Berbeda dibandingkan single web server, penggunaan multi web server dengan koneksi tinggi masih dapat berjalan lancar.

\section{KESIMPULAN DAN SARAN}

Berdasarkan hasil pengujian yang dilakukan pada setiap node, dapat disimpulkan bahwa GlusterFS telah berhasil diimplementasikan. Pengujian dilakukan dengan menggunakan beberapa skenario yaitu pengujian kerja GlusterFS dan perbandingan single web server dengan multi web server. GlusterFS telah bekerja dengan benar sesuai dengan tipe volume yang digunakan yaitu distributed-replicated dan setiap data yang tersimpan pada gluster akan otomatis sinkron pada setiap GlusterFS. Sinkronisasi telah dilakukan dengan melakukan metode pengujian seperti penambahan file dengan ekstensi yang berbeda dan ukuran yang berbeda, penambahan direktori, penghapusan file dan penghapusan direktori.

Multi web server dapat memproses request lebih baik dibandingkan dengan single web server. Perbandingan tersebut didasarkan pada banyak paket yang berhasil terkoneksi dan jumlah waktu yang dibutuhkan untuk pengujian. Single web server dapat bekerja dengan baik dengan request 1000-2500, ketika request lebih dari rentang tersebut terdapat beberapa error atau paket yang lose. Pada multi web server, paket tetap dapat berjalan dengan baik tanpa ada error hingga 5000 koneksi dengan waktu pengujian lebih baik dibandingkan single web server.

Keandalan dari multi web server telah terbukti yaitu dengan pengujian keandalan. Pengujian dilakukan dengan mematikan salah satu web server dan menguji performa dari web server. Web server tetap dapat berproses dengan baik tanpa ada perubahan berarti pada kecepatan server.

Gluster File System dapat dikembangkan dengan menambah web server. Penambahan web server ini dapat membantu pada saat dilakukannya request sehingga request dapat dibagikan ke setiap gluster client. Harapannya, beban menjadi lebih ringan. Selain itu, penulis juga menyarankan untuk dibuat server yang berfungsi sebagai load balancer sehingga setiap web server memiliki beban yang sama untuk setiap request.

\section{DAFTAR PUSTAKA}

[1] Wahyudi G, Hanggara T. 2013. Analisa Perbandingan Kinerja Antara Network File System (NFS) dan Primary Domain Controller (PDC) Samba. Jurnal Ilmu Komputer

[2] Yunis R, Telaumbanua K. 2017. Pengembangan Elearning Berbasiskan LMS untuk Sekolah, Studi Kasus SMA/SMK di Sumatera Utara. JNTETI. 6(1):32-36.

[3] Herayanti L, Fuaddunnazmi M, Habibi. 2015. Pengembangan Media Pembelajaran Berbasis Moodle. Jurnal Pendidikan Fisika dan Teknologi. 1(3):205

[4] Yudi M, M. Julkarnain, Aldela J. A. 2021. Implementasi Port Knocking untuk Keamanan Jaringan Smkn 1 Sumbawa Besar. Jurnal Informatika Teknologi dan Sains (JINTEKS). Vol. 3 No. 2, Mei 2021, hlm. 326 - 335

[5] Edi D, Betshani S. 2009. Analisis Data dengan Menggunakan ERD dan Model Konseptual Data Werehouse. Jurnal Informatika. 5(1):71-85.

[6] Rahmatulloh A, Firmansyah MSN. 2017. Implementasi Load balancing Web server menggunakan Haproxy dan Sinkronisasi File pada Sistem Informasi Akademik Universitas Siliwangi. Jurnal

[7] Erlinda T, Data M, Siregar RA. 2018. Perancangan Klaster Server Web Dengan Availabilitas Tinggi Menggunakan Teknologi Failover, Load balancing dan Distributed File. Jurnal Pengembangan Teknologi Informasi dan Ilmu Komputer. 2(12):72857292.

[8] Wijaya B, Valentino B. 2016. Building Infrastructure Distributed Database in CV. Cipta Solusi Sejahtera. Jurnal Sistem Informasi dan Komputer. 5(2):1.

[9] Donvito G, Marzuli G, Diacono D. 2014. Testing of several distributed file-systems (HDFS, Ceph and GlusterFS) for supporting the HEP experiments analysis. Journal Conference Series. 
[10] Pribadi PT. 2013. Implementasi High-Availability VPN Client pada Jaringan Komputer Fakultas Hukum Universitas Udayana. Jurnal Ilmu Komputer. $6(1)$.

[11] Muliyantoro HS. 2013. Penerapan Metode LoadBalancing Clusters pada Database server guna Peningkatan Kinerja Pengaksesan Data. Jurnal Techno Nusa Mandiri. 9(1).

[12] S ND, Suhatman R, Muslim I. 2018. Implementasi High Availability Web server pada Cloud Computing Menggunakan Pacemaker. Jurnal SNTIKI-10. (November):268-275.

[13] Novianta MA, Setyaningsih E. 2015. Sistem Informasi Monitoring Kereta Api Berbasis Web server Menggunakan Layanan GPS. Jurnal Momentum. 17(2).

[14] Harahap PH. 2010. Teknik Pendeteksian Kerusakan File Dokumen dengan Metode Cyclic Redundancy Check 32 (Crc32) [Skripsi]. Universitas Sumatera Utara: Sumatera Utara. 